\title{
Haloragodendron gibsonii (Haloragaceae), a new species from the Blue Mountains, New South Wales
}

\author{
Peter G. Wilson ${ }^{1}$ and Michael L. Moody ${ }^{2}$ \\ ${ }^{I}$ National Herbarium of New South Wales, Royal Botanic Gardens, Sydney NSW 2000 Australia \\ ${ }^{2}$ Dept. Ecology \& Evolutionary Biology, University of Connecticut, 75 N. Eagleville Rd., \\ Storrs, CT 06268-3043 USA \\ Present address: Dept. Biology, Indiana University, Jordan Hall 142, 1001 E. 3rd St., \\ Bloomington, IN 47405 USA
}

\begin{abstract}
A new species, Haloragodendron gibsonii, is described from the Blue Mountains region of New South Wales. This taxon has always been recognised as being close to $H$. lucasii, a species restricted to the Ku-Ring-gai area of Sydney, but its rank has been uncertain. Relationships within the genus in eastern Australia have now been assessed using molecular data and these support recognition of the Blue Mountains plants as a distinct species.
\end{abstract}

\section{Introduction}

In October 1982, Sydney naturalist and bushwalker Colin Gibson collected two small pieces from a plant in the Bungleboori Creek area of the Blue Mountains National Park (Gibson 1998). Unfortunately, herbarium staff did not recognise the significance of this specimen when it was brought in and it was overlooked until late 1986 when it was identified as Haloragodendron lucasii (Maiden \& Betche) Orchard. H. lucasii was originally named from a collection made in the Sydney suburb of Gordon and had been presumed extinct until its rediscovery in nearby Barra Brui, also in 1986. The Blue Mountains specimens showed some differences from those from Sydney, particularly in the unwinged fruit that sets seed (H. lucasii sens. str. has a winged hypanthium and does not appear to set seed). Orchard (1990), with only a single Blue Mountains specimen available for examination, said he was inclined to consider it as merely a variant of $H$. lucasii. The differences between the Blue Mountains and Sydney populations, however, prompted Wilson (1991) to suggest that the former might constitute a distinct subspecies. Briggs and Leigh (1988) listed this taxon as 'Haloragodendron sp. 1 (Wollongambe Creek)' then later (Briggs \& Leigh 1996) as 'Haloragodendron lucasii subsp. 1 (Wollongambe Ck.; Hind 5981)'. Recent molecular data (Moody 2005) in combination with the morphological differences support the recognition of this variant taxon at specific rank and it is here described as H. gibsonii. 


\section{Materials and methods}

In a broader study of Haloragaceae, Moody (2005) collected various species of Haloragodendron and generated sequences of the nuclear (ITS) and chloroplast ( $\operatorname{trnK}$ intron, including matK) regions. Vouchers for the eastern Australian species included in this study are shown in Table 1. Full details of techniques used, and broader, more detailed, analyses will be presented elsewhere (Moody, in prep.).

\section{Molecular Results}

A phylogenetic hypothesis derived from a parsimony analysis of the combined ITS + $\operatorname{trn} \mathrm{K}-$ matK DNA sequence dataset for the eastern Australian species of Haloragodendron is presented in Fig. 1. The eastern species form a monophyletic group with $100 \%$ bootstrap support and a branch length of 15 . There are 4 point mutations in the matK $+\operatorname{trnK}$ cpDNA region that vary between $H$. lucasii and the new species. There are 8 point mutations and 1 indel ( $1 \mathrm{bp}$ ) in ITS that vary consistently between $H$. lucasii and the new species. There is no variation between the Sydney populations in cpDNA while some autapomorphies are found between ITS sequences from the two samples derived from the Barra Brui population (Fig. 1). However, the ITS sequence data derived from one of the ex-Barra Brui plants (Moody 482: cultivated at Mt Annan) and the St Ives Chase population (Moody 486) did not vary, so the latter was omitted from the analysis. The DNA variation between $H$. lucasii and the new species is comparable to that found between $H$. monospermum and H. baeuerlenii (Fig. 1).

\section{Key to species of Haloragodendron in eastern Australia}

1. Fruits obovoid to obpyramidal, strongly angled and ribbed, or winged

2. Leaves at least $2.5 \mathrm{~cm}$ long; hypanthium and fruit distinctly winged

3. Wings conspicuously veined; anthers $2-4 \mathrm{~mm}$ long 1. H. baeuerlenii

$3^{\star}$ Wings not conspicuously veined; anthers mostly 4-6 mm long 2. H. lucasii

$2^{\star}$ Leaves usually $1-1.5 \mathrm{~cm}$ long; fruit angled and ribbed 3. H. monospermum $1^{\star}$ Fruits ovoid, obtusely angled when dry, never strongly ribbed 4. H. gibsonii

\section{Haloragodendron gibsonii Peter G. Wilson \& M. Moody, sp. nov.}

H. lucasii affinis sed floribus minoribus (petalis antheribusque brevioribus), fructibus ovoideis nunquam alatis differt.

Type: New South Wales: Cultivated, Royal Botanic Gardens, Mt Annan, Accession No. NSW498891 ex Blue Mountains National Park (Hind 5978 \& Cherry), Peter G. Wilson 1684, 15 Sep 2004 (holo NSW; iso CANB, K, US distribuendi)

Straggling shrub up to $1 \mathrm{~m}$ tall; stems 4 -angled to narrowly winged. Leaves subsessile, lanceolate, 15-25(-28) $\mathrm{mm}$ long and 2-5.5(-6) mm wide, serrate; teeth reddish, variable in size, (4-)7-12 each side. Flowering shoots (primary or lateral) terminating in a 
Table 1. Vouchers for samples of eastern Australian species of Haloragodendron used in this study

$\begin{array}{lll}\begin{array}{l}\text { Species } \\ \text { Haloragodendron lucasii }\end{array} & \begin{array}{l}\text { Voucher } \\ \text { Moody 481, CONN }\end{array} & \begin{array}{l}\text { Locality } \\ \text { Cultivated, Mt Annan Botanic Garden (ex Australian } \\ \text { National Botanic Gardens- } \\ \text { Original source: Barra Brui) }\end{array} \\ \text { H. lucasii } & \text { Moody 482, CONN } & \begin{array}{l}\text { Cultivated, Mt Annan Botanic Garden } \\ \text { (Original source: Barra Brui) }\end{array} \\ \text { H. lucasii } & \text { Moody 486, CONN } & \begin{array}{l}\text { St lves Chase } \\ \text { Cultivated, Mt Annan Botanic Garden }\end{array} \\ \text { H. sp. } & \text { Moody 480, CONN } & \begin{array}{l}\text { (Original source: Bungleboori Creek area) } \\ \text { H. monospermum }\end{array} \\ \text { H. monospermum } & \text { Moody 475, CONN } & \begin{array}{l}\text { NE of Braidwood } \\ \text { Cultivated, Australian National Botanic Gardens } \\ \text { (Original source: WNW of Kybean) }\end{array} \\ \text { H. baeuerlenii } & \text { Moody 483, CONN } & \begin{array}{l}\text { Cultivated, Mt Annan Botanic Garden } \\ \text { (Original source: Deua National Park) }\end{array}\end{array}$

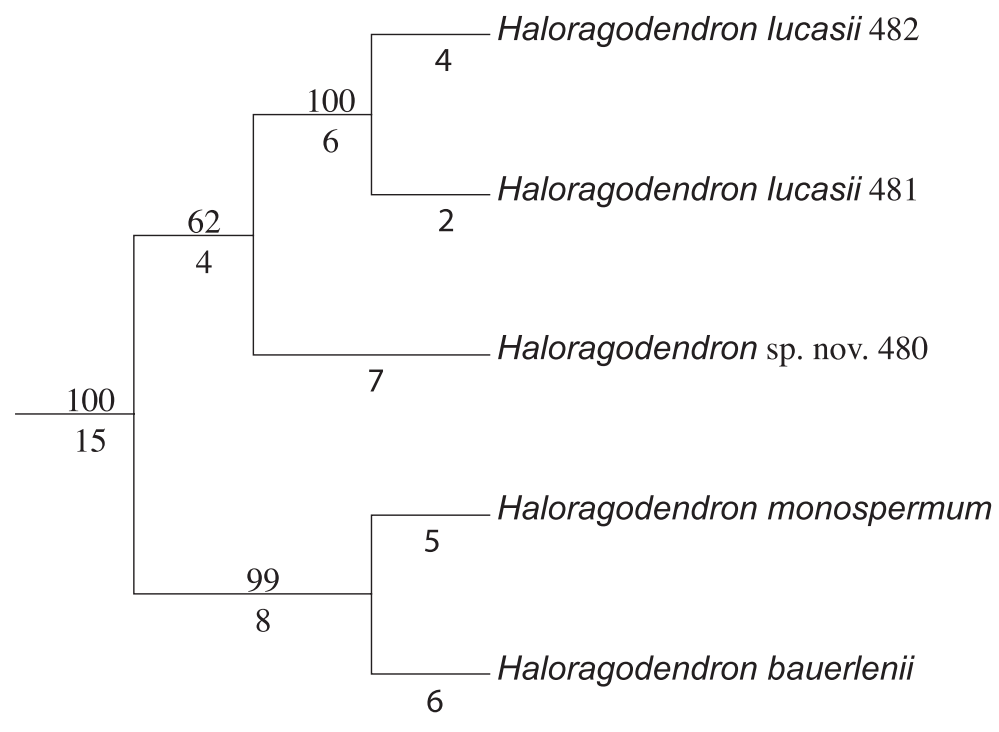

Fig. 1. Phylogenetic hypothesis of relationships among the eastern species of Haloragodendron based on combined matK-trnK cpDNA and ITS nrDNA sequence data analysed using parsimony (taken from Fig. 1.3 in Moody 2005). Numbers above branches are bootstrap support; those below are branch lengths. 
subsessile flower; lateral flowers with tapering bases 1-2.5 mm long. Primary bracts of the flowering shoot are somewhat reduced forms of normal foliage leaves that become smaller towards the apex, with the pair subtending the terminal flowers sometimes bract-like (lacking teeth, browning off and deciduous), 3.2-4.5 mm long, 0.7-0.9 $\mathrm{mm}$ wide. Bracteoles $1.8-2.3 \mathrm{~mm}$ long, $0.4 \mathrm{~mm}$ wide, inserted very close to the node. Flowers \pm sessile, solitary; petals 6-9.5 mm long, 2.5-3 mm wide; stamens 8, filaments 3-3.5 $\mathrm{mm}$ long, anthers $2.5-4.5 \mathrm{~mm}$ long, apparently dimorphic, with the antesepalous 0.5-1 mm longer than the antepetalous. Ovules 4. Immature fruit ovoid, green, 5-6 $\mathrm{mm}$ long and $4-5 \mathrm{~mm}$ broad with a fleshy pericarp; mature fruit semipersistent on the plant, dry, dark brown, 4.5-5 mm long and 2.5-3.5(-4) mm broad, \pm ovoid but weakly 4 -angled and with a few coarse papillae in the lower half; pericarp woody, $0.8-1.0 \mathrm{~mm}$ thick. Seed solitary. Fig. 2.

Notes: this species is close to $H$. lucasii but differs by the \pm ovoid, unwinged hypanthia and fruits, and the smaller flowers with petals 6-9.5 mm (compared with 9.5-12) $\mathrm{mm}$ long and anthers $2.5-4.5 \mathrm{~mm}$ (compared with $5.5-7 \mathrm{~mm}$ ) long. The petals are not as markedly twisted in bud.

Etymology: the species is named for Colin P. Gibson, who made the first collection.

Distribution: seems to be confined to Bungleboori Creek and its tributaries, Blue Mountains National Park.

Habitat and ecology: in more protected sites, e.g. sheltered gullies and on creek banks, plants have been recorded in open forest of Eucalyptus oreades with Ceratopetalum apetalum, Logania albiflora, Todea barbara, Gahnia sp., and Prostanthera sp. In more exposed sites, e.g. dissected cliff-lines and pagodas, they have been found in heath associated with species such as Allocasuarina distyla, Banksia ericifolia, B. conferta, Eucalyptus stricta, Leptospermum trinervium, Acacia hamiltoniana, Olax stricta and Caustis pentandra.

Conservation status: in Briggs and Leigh (1996) this species is coded as 2RCat (i.e., rare but adequately conserved with a total known population of $1000+$ plants that are all known to occur in a conservation reserve). Population numbers at individual sites are mostly high, although at one site the plants were described as 'either gregarious or cloning. There is no evidence available to assess clonality, but the species certainly regenerates from seed: one herbarium sheet (Keith s.n., 23 Feb 1999) consists of seedlings 15-35 cm high that had come up subsequent to a wildfire in 1994.

Selected specimens examined: New South Wales: Central Tablelands: Bungleboori Creek, Gibson s.n., 3 Oct 1982 (NSW 284758); Bungleboori Creek, Jones s.n., 26 Feb 1992 (NSW 262806); Yarramun Creek, Lembit s.n., 7 Dec 1986 (NSW 171423, HO); Hole-in-the-Wall Creek, Gibson 13, 26 Dec 1988 (NSW); E of Mt Norris towards Bungleboori Creek, Hind 5981 \& Cherry, $26 \mathrm{Feb} 1990$ (NSW).

\section{Acknowledgments}

We thank Tracey Armstrong and Trish Meagher (Mt Annan Botanic Garden) for their assistance with cultivated plants, and Gill Towler and Surrey Jacobs for field companionship. We thank Catherine Wardrop for the fine illustration. 


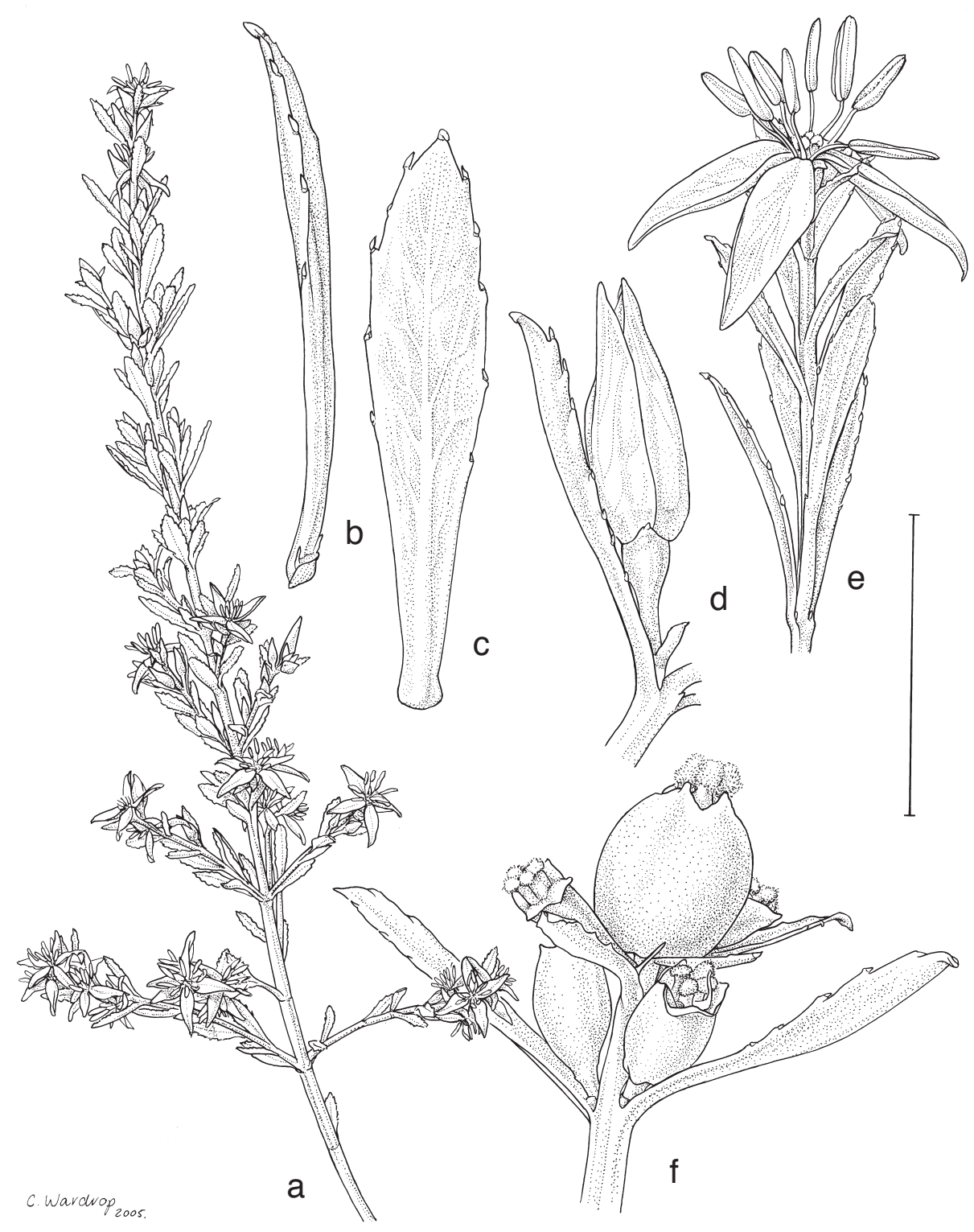

Fig. 2. Haloragodendron gibsonii. a, habit; b, c, leaf; d, bud (just beginning to open); e, flower; f, developing fruit (all from Wilson 1684). Scale bars: $\mathrm{a}=75 \mathrm{~mm}$; $\mathrm{b}-\mathrm{d}=8 \mathrm{~mm} ; \mathrm{e}, \mathrm{f}=10 \mathrm{~mm}$. 


\section{References}

Briggs JD \& Leigh JH (1988) Rare or threatened Australian Plants, revised edition. Australian National Parks and Wildlife Service Special Publication No. 14.

Briggs JD \& Leigh JH (1996) Rare or threatened Australian Plants, 1995 revised edition. (CSIRO Publishing: Collingwood)

Gibson C (1998) Barabruiensis and Bunglebooriensis. The Bushland Bulletin [Newsletter of the Bankstown Bushland Society] No. 25: 6, 10.

Orchard AE (1990) Rediscovery of Haloragodendron lucasii (Haloragaceae). Telopea 3: 593-595. Moody ML (2005) Systematics of the Angiosperm Family Haloragaceae R. Br. Emphasizing the Aquatic Genus Myriophyllum: Phylogeny, Hybridization and Character Evolution. (Unpublished PhD thesis: University of Connecticut)

Wilson PG (1991) Haloragaceae. Pp. 208-219 in Harden GJ (ed.) Flora of New South Wales vol. 2. (New South Wales University Press: Kensington)

Manuscript received 20 October 2005, accepted 19 December 2005 